\title{
VOETSTOOTS - SALE OF IMMOVABLE PROPERTY, THE LAW OF LEGEND?
}

\author{
By Jean-Ray Pearton*
}

\section{Introduction}

Is the sale of immovable property, voetstoots, the law of legend? To answer this question properly, let us refer to the definition of a voetstoots clause and then assess how the Consumer Protection Act (herein after referred to as the CPA) ${ }^{1}$ applies to the voetstoots clause in a modern-day business transaction regarding immovable property.

A voetstoots clause is a clause which is inserted into the contract of sale during the sale of immovable property. It provides that the property in question is sold, 'as it stands and with all faults'. ${ }^{2}$ This means that property, in most cases a house, is sold as it is, completely disregarding any defects the house may have. Defects can be anything from a faulty geyser to decommissioned plug points in one's new living room. Such a sale of property will not, however, be accepted without scrutiny due to the consumer-friendly legislation enacted under the Constitution, ${ }^{3}$ namely the CPA.

For easy reference, an example of a voetstoots clause will be included: 'The property is sold voetstoots in the condition in which it stands and the seller gives no warranty with regard thereto, whether express or implied. 4

The question that needs to be asked: 'Can a voetstoots clause still be valid under the CPA?' The answer is: Yes, unless you are a developer, investor or speculator.

\section{The common law position}

Before exploring the application of the CPA, reference must be made to the common law position for a brief background. Our common law position is that a seller is liable to a purchaser for all latent defects in

\footnotetext{
Third year LLB student, University of Pretoria.

Act 68 of 2008.

Mouton $v$ Wessels 19513 SA $147(\mathrm{~T})$.

The Constitution of the Republic of South Africa, 1996.

R Sharrock Business Transactions Law (1992) 177.
} 
the property sold for a period of three years after the discovery of the defects. ${ }^{5}$ Latent defects refer to defects, which exist in hidden or dormant form but are usually capable of being brought to light. Examples of latent defects are: hidden, damp, leaking pools and structural problems, which cannot be seen with the naked eye. Patent defects refer to defects, which are readily seen, discovered or understood to be defects. This could be a large and noticeable crack in the wall. It is reasonable to expect that such defects will be noticed by the purchaser as he has a duty to inspect the goods or property thoroughly before purchase.

As a consequence of the harshness of this common law provision, the voetstoots clause has been included in all agreements of the sale of immovable property and offers the seller protection from the discovery of latent defects by the purchaser after the sale. ${ }^{6}$ This applies across the board, except where the seller acted fraudulently by either being aware of the defect and not disclosing it, or concealing the defect from the purchaser or agent.

\section{The application of the CPA}

The CPA provides for a statutory duty of disclosure in consumer transactions. The Act expands on the common law obligation to disclose latent defects by requiring suppliers to disclose material facts and to correct misapprehensions on the part of the consumer, if failing to do so would amount to a deception. If the seller hides defects in a property on purpose, the seller will not be protected. In other words, the voetstoots clause will not protect a seller who knows of a defect in the property but does not tell the purchaser about the defect. Sellers should also be aware that the CPA goes even further than a simple failure to tell the purchaser about a defect in that the voetstoots clause will also not protect a seller who tells a half-truth. ${ }^{7}$

The purchaser also has certain common law responsibilities when buying property, inter alia, the 'duty to inspect'. ${ }^{8}$ The purchaser must inspect the property and must be aware of the condition of the property as the purchaser will have to 'live' with any defects. If the purchaser sees defects that are not acceptable, the purchaser must write into the offer to purchase that the problem must be fixed by the seller prior to the registration of transfer. If the seller accepts the offer to purchase with this condition, the seller has agreed to fix the problem. 162.

AJ Kerr The Law of Sale and Lease 3rd Edition (2004) 146.

A Du Plessis 'Voetstoots clause' (2012) Issue 372 Personal Finance Letter page.

8 HG Mackeurtan \& GRJ Hackwill Sale of goods in South Africa (1984) 160. 
In terms of the CPA, the consumer is entitled to receive goods that are reasonably suitable for the purpose for which they are generally intended, are of good quality, in good working order and free of any defects.

The definition of 'goods' in section 1 of the CPA has been amplified to include a legal interest in land or other immovable property.

In terms of this, the balance has shifted with transactions that are covered by the CPA. The operation of the voetstoots clause is excluded from transactions that are concluded in the ordinary course of the supplier's business by operation of section 55 of the CPA 'Consumers right to safe, good quality goods (except goods purchased on auction).' Section 55 entitles the purchaser to receive property or goods that are reasonably suitable for the purpose for which they are generally intended and are of good quality, in good working order and free of any defects. The CPA only applies to transactions that are concluded in the ordinary course of the supplier's business. Therefore it would, for instance, apply to property sold by a developer and to the services provided by estate agents to sellers (this could be an article on its own), but not to once-off transactions between purchasers and sellers of property.

Sections 55 and 56 of the CPA, quoted above, clearly bar the seller from including a voetstoots clause in an agreement by creating an implied warranty by the seller that the goods are free of latent and patent defects. The CPA therefore does away with the voetstoots clause and any other contractual stipulation such as a 'no warranties' clause - whereby the seller may have sought to limit his liability for defects in transactions where the Act applies. However, knowing when the consumer's rights, provided by section 55 , do not apply to the transaction is important to resolve the recurring confusion amongst the public.

If the purchaser has been informed, expressly or in writing, that the property was offered in a specific condition which details all defects - and, if the purchaser has expressly agreed to accept the property in that condition or acted in a way that was consistent with accepting the property in that condition, it becomes irrelevant whether the defect was latent or patent. This implies that the voetstoots clause can still be included in a contract on condition that the seller has clearly disclosed all defects to the purchaser and the purchaser has accepted this. The defects could be included in the contract by the means of an annexure to the contract or, if the contract prepared by the agent allows for the addition of special information, under a specific clause.

The situation differs with once-off sales where the seller is a developer, investor or speculator. Such individuals or companies 
cannot exclude liability for defects by way of a voetstoots clause. In once-off sales if latent defects are not disclosed, or if the property bought by the purchaser differs materially from the specifications, the purchaser may have the right to refuse to take transfer.

\section{Case law}

Here is relevant case law to clarify the position and to shed some light on the position of an agent.

\subsection{Banda \& Another $v$ Van der Spuy \& another 9}

In this case, only an expert would have recognised the defect and the seller could not be blamed for it. The voetstoots clause could therefore be enforced. If the house was sold subsequent to the CPA coming into effect on 31 March 2011, the estate agent might well have been regarded by the court as a supplier of the property and would have been liable for the defect. Agents will not, like sellers, be protected by the voetstoots clause. The court found that the defects that existed at the time of the conclusion of the sale agreement were latent in nature. The claim was dismissed.

\section{2 Hay and Another $v$ Hilder $^{10}$}

The parties had entered into an agreement of purchase and sale whereby the plaintiffs bought a house from the defendant. The agreement contained a voetstoots clause to the effect that the plaintiffs acknowledged that they were aware that there was damp in the games room. After moving into the house, the plaintiffs found that water flooded into the games room whenever there was heavy rain. The court found that the plaintiffs had proved that the defendant's agents failed to disclose the defect dolo malo. The defendant was bound by her agent's non-disclosure and was therefore liable for the fraudulent non-disclosure of the fact that the water had seeped into the room. The appeal was upheld with costs.

\subsection{Odendaal v Ferraris ${ }^{11}$}

In terms of an agreement of sale, the respondent had purchased the appellant's property. After taking occupation, he discovered a host of defects which were not previously revealed to him and some of which 
he alleged had been actively withheld from his knowledge. He notified the appellant of his dissatisfaction and instructed his bank to delay transfer. The appellant then sought to have him evicted. The appellant failed to get statutory approval for certain alterations to the main structure on the property. The court agreed that the absence of statutory approval constituted a latent defect. If a buyer hopes to avoid the consequences of a sale, he must show not only that the seller knew of the latent defect and did not disclose it, but also that he or she also deliberately concealed it with the intention to defraud. The respondent was unable to prove the latter, and the appeal was upheld.

Estate agents may be of the opinion that the CPA does not apply to private sellers (correct), or to their agents (incorrect) - because the agents are regulated by the Estate Agency Affairs Board - and are therefore exempt from the provisions of the CPA. ${ }^{12}$

This opinion appears to arise from a misinterpretation of the scope of the obligation of intermediaries to disclose which is regulated by other national legislation (section 27 of the Act).

There are lawyers who point out that estate agents are professional purveyors of a 'product' - the product being information on the properties on the agent's books. With regard to information on properties, which agents communicate, both purchasers and sellers enjoy protection under the CPA, because they are 'consumers' of the product supplier (the agent). It is clear that estate agents do bear accountability in terms of the CPA for the material information about a property which they communicate to both purchasers and sellers. It will probably take a test court case or two to convince some estate agents on the reach (and the teeth) of the CPA.

Where property is sold by a developer and the provisions of the Act do apply, the voetstoots clause should not be included in a sale agreement as it will be in conflict with the Act, which creates an implied warranty in any transaction under its scope. ${ }^{13}$ The warranty provides that the goods sold are reasonably suitable for the purposes for which they are intended, are of good quality, in good working order and free of any defects, whether latent or patent. If the transaction is one in which a developer, investor or speculator is selling his home, the provisions of the Act will apply and the voetstoots clause may, and should, still be included in the agreement of sale. showthread.php/10305-Estate-agents-are-liable-under-the-CPA (accessed 24 June 2012).

13 RH Christie The law of contract in South Africa (2011) 19, 160, 166 \& 306. 
Developers and estate agents must review their standard contracts to ensure that they comply with the requirements of the CPA. Most importantly, the contracts must be prepared in plain and understandable language and must contain terms that are fair, just and reasonable. ${ }^{14}$ Any defects in a property must be disclosed to the prospective purchaser, and must be reduced to writing and signed by both parties. The effect of the CPA may seem harsh to certain members of the business community. However, it is important to keep in mind that the purpose of the CPA is to protect the rights of consumers and to empower them to be able to rely on these muchneeded rights. Section 61(1) of the CPA introduces no-fault liability for damages that arise as a consequence of any defect of goods. The CPA clearly does not spare the rod to ensure that goods supplied are safe and of good quality. Furthermore, it creates substantial penalties for the non-compliant!

\section{Conclusion}

Looking at the entire situation, it is highly unlikely that there will be any radical change in the way South African law applying to the sale of immovable property is interpreted. Purchasers must therefore take great care to do their homework, analyse their financial position and refrain from signing an offer until they are one hundred percent certain they want and can afford the property they have their eye on. It seems, however, that the voetstoots clause is still law rather than legend. 